\title{
The Effect of Loss of the Most Fertile Agricultural Land on the Reduced Productivity of Strategic Commodities - Case Study
}

\author{
Jan Szturc', Jana Podhrázská1,2*, Josef Kučera ${ }^{1,2}$ \\ 1 Department of Applied and Landscape Ecology, Mendel University in Brno, Brno, Czech Republic \\ 2 Research Institute for Soil and Water Conservation, v.v.i., Department of Land Consolidations and \\ Landscape Use, Lidická 25/27, 60200 Brno, Czech Republic \\ * Corresponding author's e-mail: podhrazska.jana@vumop.cz
}

\begin{abstract}
This report presents an analysis of productivity trends in a suburban beet-producing region impacted by the loss of agricultural land by land claims. The analysis was conducted in the model cadastral locality of Dolní Heršpice. In order to calculate the potential production of agricultural crops, the authors selected one sowing structure that has been applied starting from 1950 until present. The choice of particular crop succession was based on the exemplary sowing structure for beet-producing regions provided by the Central Institute for Supervising and Testing in Agriculture. The calculation of the potential production of agricultural crops was divided into three time intervals, 1950-1990, 1990-2006, and 2006-2019. In the period from 1950 to 2019, the studied locality underwent a loss of arable land of $145.19 \mathrm{ha}$. The yield in a particular time interval was derived from the selected sowing procedure and subsequently recalculated to the surface area of the lost arable land. The results show that in the time interval 1950-1990, the produced agricultural crops could have reached a total of 26,975.28 tons. In the period 1990-2006, the yield of crops could be 5,598.85 tons, and in the period 2006-2019, a total of 8,423.6 tons of agricultural crops could have been achieved in the studied locality. The total yield for the entire monitored period could represent $40,997.50$ tons of agricultural crops. The productivity by hectare oriented cultivation in all the monitored time intervals to prevailing sugar beet and potatoes. The analysis was compared with the statistical data on the development of sowing areas, production and yields of the monitored crops in the Czech Republic. The presented study documents the trend of arable land loss and potential threat of insufficient production, particularly in the case of strategic commodities such as sugar beet in beet-producing regions.
\end{abstract}

Keywords: arable land claims, agricultural crop production, yields, sowing areas.

\section{INTRODUCTION}

The quality of agricultural land fund is assessed by land valuation. Approximately $9 \%$ of agricultural land is represented by highly or very highly productive soils, $11 \%$ of soils are medium productive, $48 \%$ have low or very low productivity, and up to $32 \%$ represent the soils with less significant or negligible productivity. The regions with higher altitude can be considered less favourable for agricultural management. More than $20 \%$ of agricultural land fund is situated above $500 \mathrm{~m}$ a.s.1. in the Czech Republic (CR); agricultural regions are categorized into agriculturally productive areas, disadvantaged areas, and vulnerable areas. Agriculturally productive areas are zoned into four productive types, of which the corn productive area (CPA) and beet productive area (BPA) represent the areas with high productive potential. At the same time, these areas are often situated close to large agglomerations and face high pressure for other than agricultural land use. The period 1999-2017 recorded a total loss of up to 77 thousand ha of agricultural land, which on average represents a loss of ca. 4 thousand ha per year and more than 11 ha per day. At the expense of agricultural land, the same period marked an increase, particularly in forest areas, by more than 37 thousand ha, other areas by ca. 
31 thousand ha, and water bodies by ca. 7 thousand ha (Ministry of Agriculture CR, 2018).

This resulted in a loss of high-quality valuable arable land, which also means lower availability of good fertile soils for future generations and consequent loss of biodiversity, along with the changes in the terrain relief and overall landscape features. The changing climatic conditions have also played a significant role in agriculture and will have both direct and indirect effects, mostly initiated by increasing temperatures. In particular, the conditions of stands for growing crops are changing, e.g., along with changes in winter characteristics, length of vegetation period, or temperature sums and distribution of precipitation (Žalud et al., 2020). All these factors may lead to reduced cultivation of basic commodities in so far exploited areas and to a search for other territorial and technical approaches in order to preserve their production. In addition, such situation relates to the self-sufficiency of CR in food, which is currently a broadly discussed issue, and there are various approaches to its definition (Pulkrábek et al., 2019). Sugar beet (Beta vulgaris var. altissima.) is among the most productive crops cultivated in corn- and beet-growing areas. Sugar beet is a crop with high agronomical added value. It is a strategic energetic crop, occupying the $15^{\text {th }}$ position in the most frequently grown crops worldwide. Correct growing of beet involves a severalyear sowing schedule alternated with cereals or, optionally, other wide-row crops (Chochola, 2010). Owing to increasing population, there is growing demand for sugar, both for human feeding and as a renewable energy source. Beet growing has a long tradition in CR, which has long been among significant producers of sugar beet and in this regard is on the level of the most developed countries worldwide (Kotyza et al., 2019). At present, the acreage of the sowing areas more or less stagnates between years (Ministry of Agriculture CR, 2019). It should be noted that agricultural land is constantly decreasing, and keeping up with the competition within EU in production of strategic commodities will gradually become more and more difficult. The presented report analyses the trend in productivity of a suburban beet-producing area impacted by the loss of agricultural land by land claims.

\section{METHODOLOGY AND DATA}

Potential production of agricultural crops was derived from historic and current data on the yields of selected crops provided by the Czech Statistical Office (CSO). By its position, the study locality of Dolní Heršpice investigated in this report (Fig. 1) belongs to a beet-producing area (BPA), and so based on the information obtained from the Central Institute for Supervising and Testing in Agriculture (CISTA), a model 8-year rotation of crops was selected, which was applied in all calculations of potential production during the entire monitored period. The calculation of potential production was divided into three time intervals, 1950-1990, 1990-2006 and 2006-2019. The data on the proportion of arable land acreage in the particular time intervals was used.

The yield in a particular time interval was derived from the selected rotation of crops and recalculated to the surface area of the lost arable land. Potential yields of selected agricultural crops were established both individually, for each crop in the particular interval, and as a total for the entire monitored period.

\section{RESULTS}

Calculation of the potential agricultural crop productivity covered the period starting from 1950 until present. The results were obtained based on the data from the analysis of landscape changes, i.e., on the basis of the arable land acreage in the particular time period (in this case, 1950-2019), and using the data provided by the Czech Statistical Office (CSO). The monitored time intervals were selected on the assumption that these years marked some changes associated with agricultural production (1950 - gradual collectivization of agriculture, 1990 - change in political regime, 2006 - CR accession to EU, 2019 - present state). The trend in the changes of arable land acreage in the studied locality is documented in Figure 2.

The study locality of Dolní Heršpice is situated in a beet-producing area (BPA); therefore, to calculate the potential production of agricultural crops, the authors selected one sowing structure that has been applied since 1950 until present. Succession of individual crops was derived from an exemplary 8-year sowing procedure for BPA: oat $(\mathrm{O})$, lucerne $(\mathrm{L})$, winter wheat $(\mathrm{WW})$, potatoes 

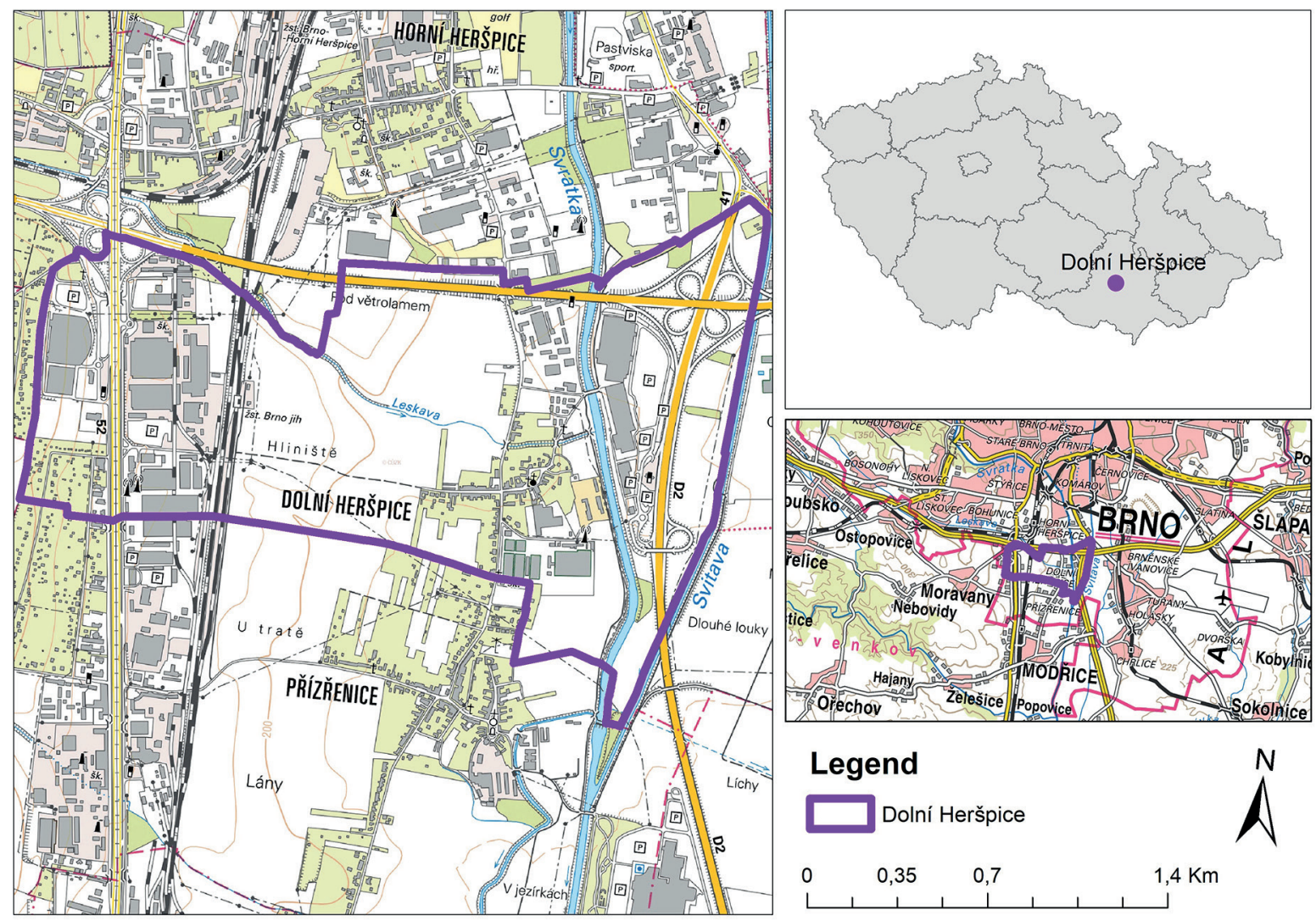

Fig. 1. Survey map of the study locality

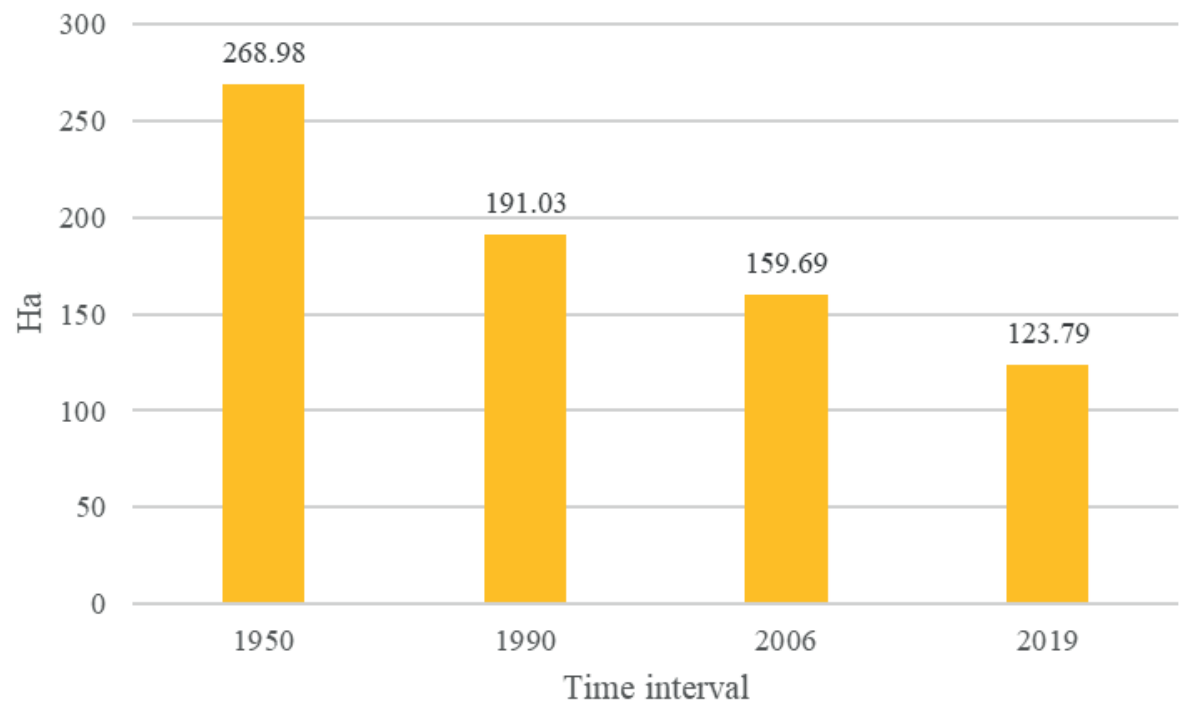

Fig. 2. Trend in arable land surface area in the Dolní Heršpice cadastral area

(P), winter wheat, spring barley (SB), sugar beet (B), and spring barley.

Due to significant inter-annual increases/decreases in the yields of individual crops, the mean crop yield for a rotation period of one sowing procedure was used, i.e., the potential yield of e.g. spring barley for the period 1950-1957 was determined by its mean yield (Table 1). A similar approach was used for calculating the mean yields until 2019. Winter wheat and spring barley are mentioned in the Table only once, because they are repeated in the sowing succession.

As the authors were not able to determine the sowing areas for individual crops in the particular 
Table 1. Example of calculation of hectare yields of selected crops and their mean values

\begin{tabular}{|c|c|c|c|c|c|c|c|c|c|c|c|c|}
\hline \multirow{3}{*}{ Period } & \multicolumn{2}{|l|}{0} & \multicolumn{2}{|l|}{$\mathrm{L}$} & \multicolumn{2}{|c|}{ WW } & \multicolumn{2}{|l|}{$\mathrm{P}$} & \multicolumn{2}{|c|}{ SB } & \multicolumn{2}{|l|}{$B$} \\
\hline & \multicolumn{2}{|c|}{ Yield (t.ha-1) } & \multicolumn{2}{|c|}{ Yield(t.ha-1) } & \multicolumn{2}{|c|}{ Yield (t.ha-1) } & \multicolumn{2}{|c|}{ Yield (t.ha-1) } & \multicolumn{2}{|c|}{ Yield (t.ha-1) } & \multicolumn{2}{|c|}{ Yield (t.ha-1) } \\
\hline & t.ha-1.y-1 & $\varnothing$ & t.ha-1.y-1 & $\varnothing$ & t.ha-1.y-1 & $\varnothing$ & t.ha-1.y-1 & $\varnothing$ & t.ha-1.y-1 & $\varnothing$ & t.ha-1.y-1 & $\varnothing$ \\
\hline 1950 & 1.57 & \multirow{8}{*}{1.81} & 3.04 & \multirow{8}{*}{4.13} & 2.00 & \multirow{8}{*}{2.08} & 13.90 & \multirow{8}{*}{14.02} & 1.92 & \multirow{8}{*}{2.03} & 30.02 & \multirow{8}{*}{25.77} \\
\hline 1951 & 1.76 & & 4.11 & & 2.10 & & 11.72 & & 1.94 & & 21.64 & \\
\hline 1952 & 1.87 & & 3.63 & & 2.23 & & 13.00 & & 2.00 & & 22.02 & \\
\hline 1953 & 1.66 & & 3.64 & & 2.08 & & 15.96 & & 1.96 & & 24.82 & \\
\hline 1954 & 1.86 & & 4.04 & & 1.59 & & 13.86 & & 1.87 & & 26.95 & \\
\hline 1955 & 1.99 & & 5.48 & & 2.19 & & 13.06 & & 2.17 & & 29.59 & \\
\hline 1956 & 2.04 & & 4.91 & & 2.31 & & 16.17 & & 2.27 & & 20.84 & \\
\hline 1957 & 1.73 & & 4.21 & & 2.14 & & 14.49 & & 2.11 & & 30.27 & \\
\hline
\end{tabular}

years, a simplified schedule with one crop covering the entire acreage of arable land in the particular year was used.

The Figure 3 shows the trends in the mean yields of particular agricultural crops in the period from 1950 to 2019 , calculated by using the method presented in Table 2, which was divided into 8-year time intervals.

The calculation of the potential agricultural crop production was divided into three time intervals, 1950-1990, 1990-2006, and 2006-2019. The yield in a particular time interval was derived from the selected sowing procedure and recalculated to the acreage of the lost arable land (Table 2).

The calculated results showed that when applying the model sowing procedure typical of a beet-producing area, starting from 1950 until present, a total yield of 40,997.50 tons of agricultural crops could have been achieved. The Table 3 gives a detailed survey of the potential production of individual agricultural crops in the particular time interval relative to the land acreage. Winter wheat and spring barley are mentioned in the Table 3 only once, because they are repeated in the sowing succession, and their potential yield is included twice.

This table shows that in the time interval 1950-1990, a total yield of 26,975.28 tons of agricultural crops could have been achieved. Further, in the interval 1990-2006, the yield of crops could have reached 5,598.85 tons, and between 2006-2019, the studied locality could have achieved a total of 8,423.36 tons of agricultural crops. The productivity by hectare would have oriented cultivation in all the monitored time intervals to prevailing sugar beet and potatoes.

Table 2. Loss of arable land between the studied periods

\begin{tabular}{|c|c|c|}
\hline $1950-1990$ & $1990-2006$ & $2006-2019$ \\
\hline Surface area (ha) & Surface area (ha) & Surface area (ha) \\
\hline 77.95 & 31.34 & 35.9 \\
\hline
\end{tabular}

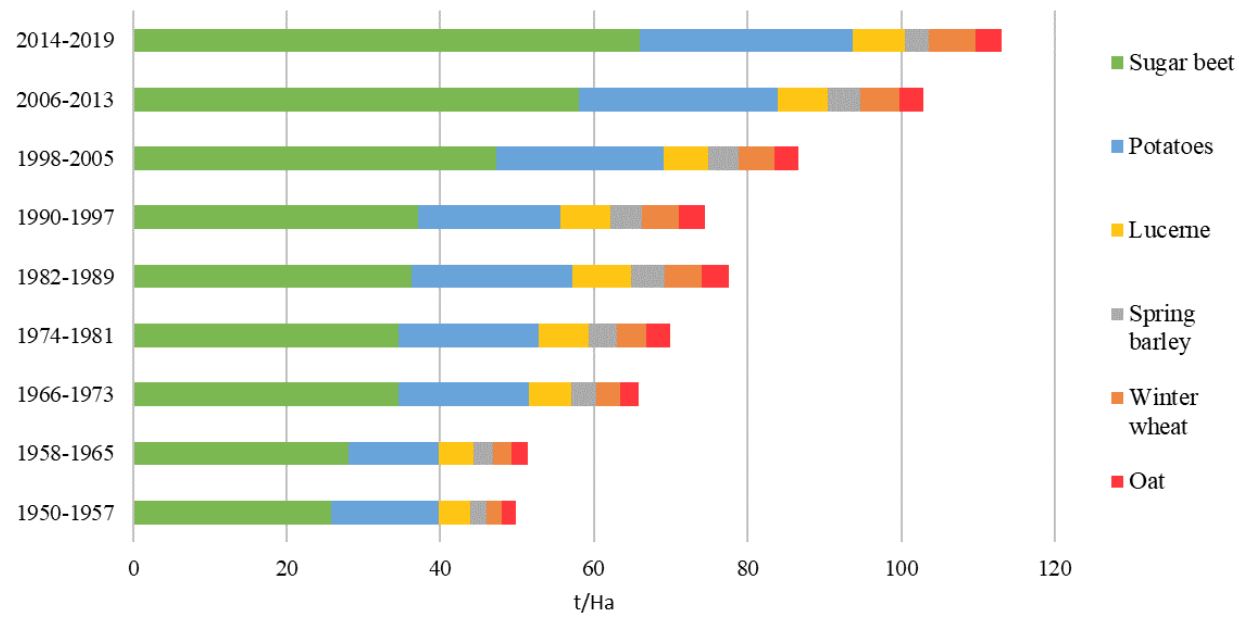

Fig. 3. Trends in the mean yields of selected agricultural crops in the studied locality 
Table 3. Potential production of selected agricultural crops in particular time intervals

\begin{tabular}{|l|c|c|c|c|}
\hline \multirow{2}{*}{ Crop } & $1950-1990$ & $1990-2006$ & $2006-2019$ & Total \\
\cline { 2 - 5 } & Production $(\mathrm{t})$ & Production $(\mathrm{t})$ & Production $(\mathrm{t})$ & $1,448.47$ \\
\hline Oat & $1,008.28$ & 205.24 & 234.95 & $3,077.48$ \\
\hline Lucerne & $2,212.9$ & 386.62 & 477.96 & $3,952.17$ \\
\hline Winter wheat & $2,562.02$ & 589.19 & 800.96 & $9,537.39$ \\
\hline Potatoes & $6,349.81$ & $1,266.21$ & $1,921.37$ & $3,476.42$ \\
\hline Spring barley & $2,432.82$ & 508.96 & 534.64 & $19,505.56$ \\
\hline Sugar beet & $12,409.45$ & $2,642.63$ & $4,453.48$ & $40,997.50$ \\
\hline Celkem & $26,975.28$ & $5,598.85$ & $8,423.36$ & \\
\hline
\end{tabular}

\section{DISCUSSION}

The results of the presented report document the loss in soil productivity due to land claims, despite the fact that the hectare yields of the monitored commodities during the past 70 years continually grew, as shown by the data depicted in Figure 3. In order to compare the presented model study with the situation in the Czech Republic, the data on the sowing areas, production and yields of crops monitored in CR were used, based on the information from the Czech Statistical Office (see Figs. 4 to 7).

The graphs show that production of cereals between 1950-2019 increased almost three times, along with their yields; the sowing areas are almost similar to those in the 1950s. The proportion of fodder crops decreased after 1990, but their production grew after 2006 and compared to 1950 , their yields had increased more than three times. The least advantageous trend can be observed in the case of potatoes, despite the fact that their yields increased compared to 1950 almost twice; their sowing areas were significantly reduced and production dropped to one tenth of that of 1950. The sugar beet production displayed a decreasing trend - reduction by a third in 2019 compared to 1950; in addition, the sowing areas dropped to a third. Nevertheless, its yields between these years had grown more than twice.

Concerning the monitored sowing areas as a whole, their acreages increased in the period $1950-1990$ by 127,400 ha, but starting from this year, there is a considerable loss (in the period 1990-2006 by 864,633 ha, between 2006 and 2019 by an additional 129,395 ha). In total, from 1950 until 2019, the sowing areas thus decreased by almost 30 percent. In the studied locality of Dolní Heršpice, the acreage of arable land decreased by more than 50 percent. The highest land loss was recorded between 1950-1990 (see Table 2), which on the one hand can be attributed to a longer monitored period and on the other hand to the onset of development of infrastructure, residential and industrial areas in the suburban area of the city of Brno during the second half of the $20^{\text {th }}$ century.

The records of the sowing areas are updated annually by the Agrarian Chamber of the Czech Republic. Since the year 1920, when the acreage of the sowing areas started to be monitored, the territories of Bohemia, Moravia

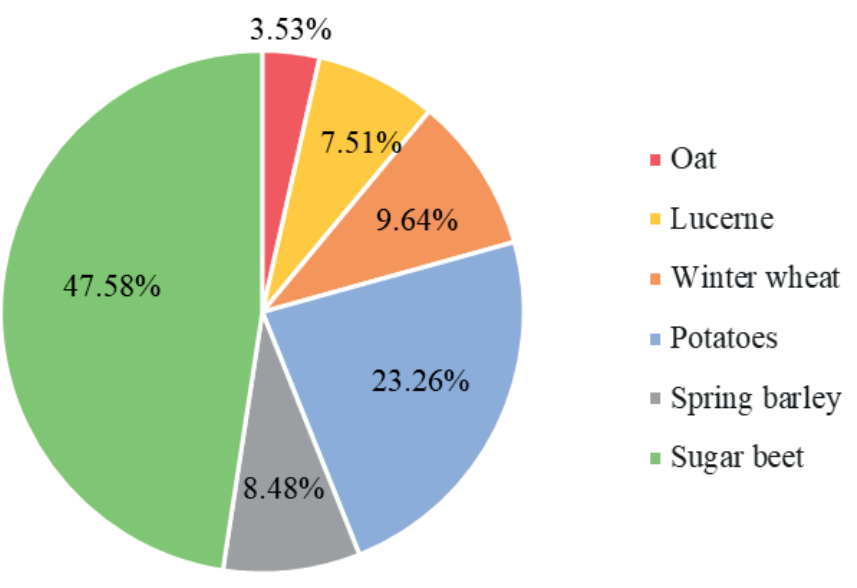

Fig. 4. Percentage of production of selected agricultural crops 


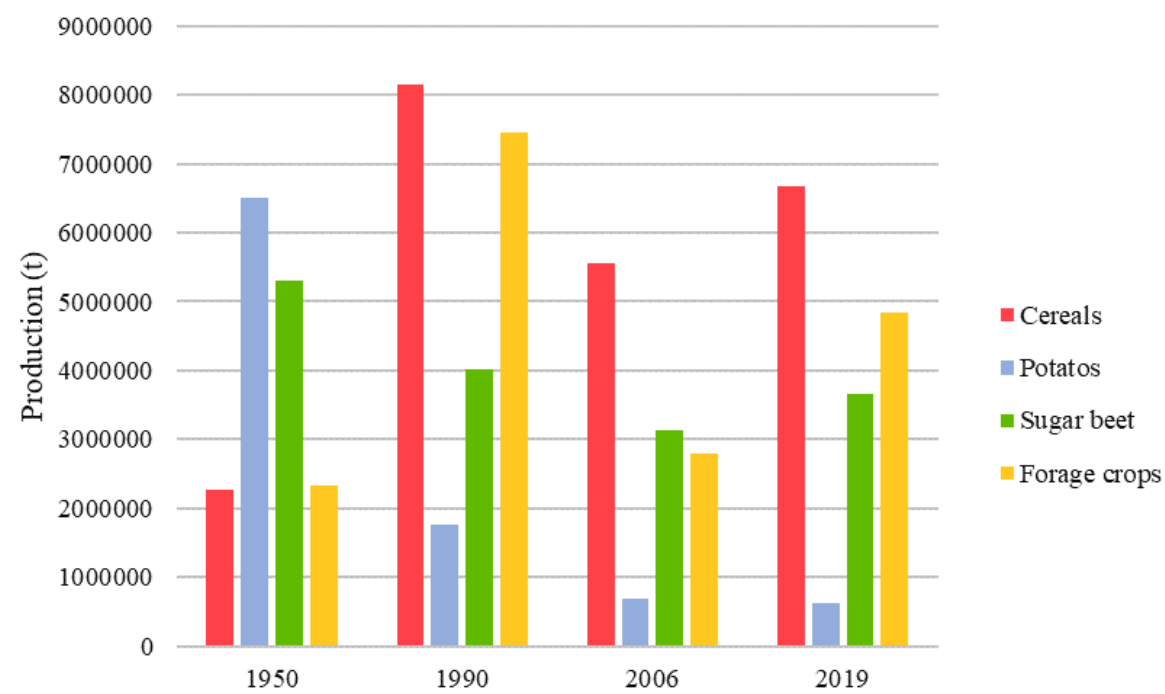

Fig. 5. Production of selected crops in the studied time period

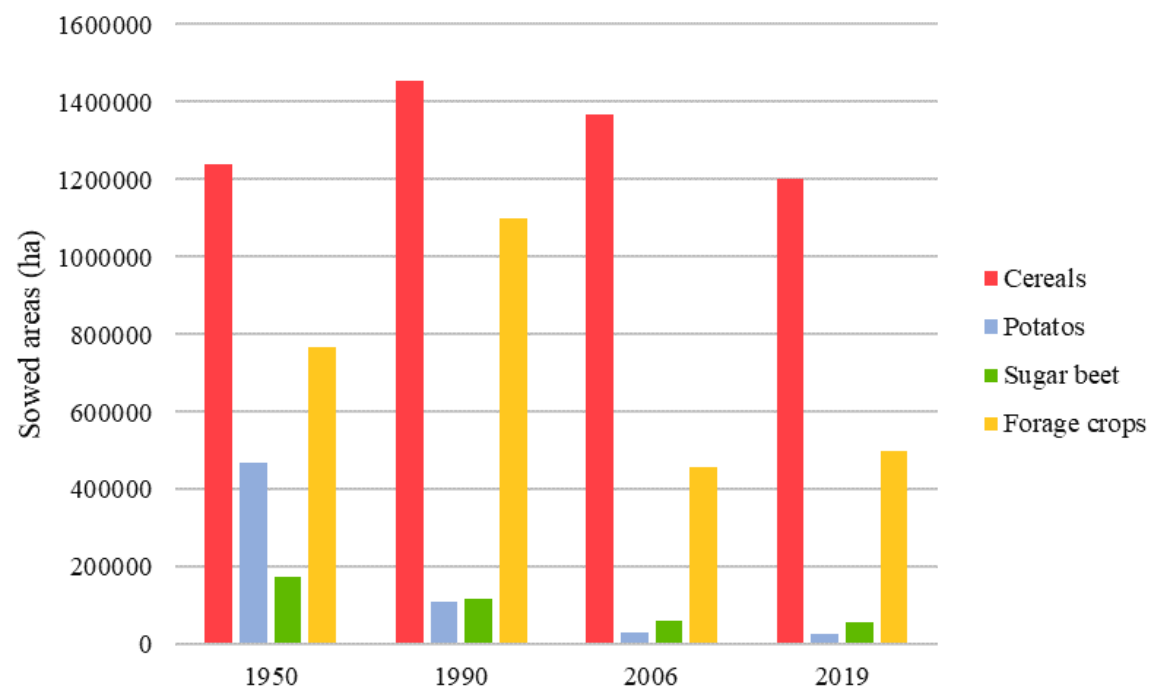

Fig. 6. Sowed areas of selected crops in the studied time period

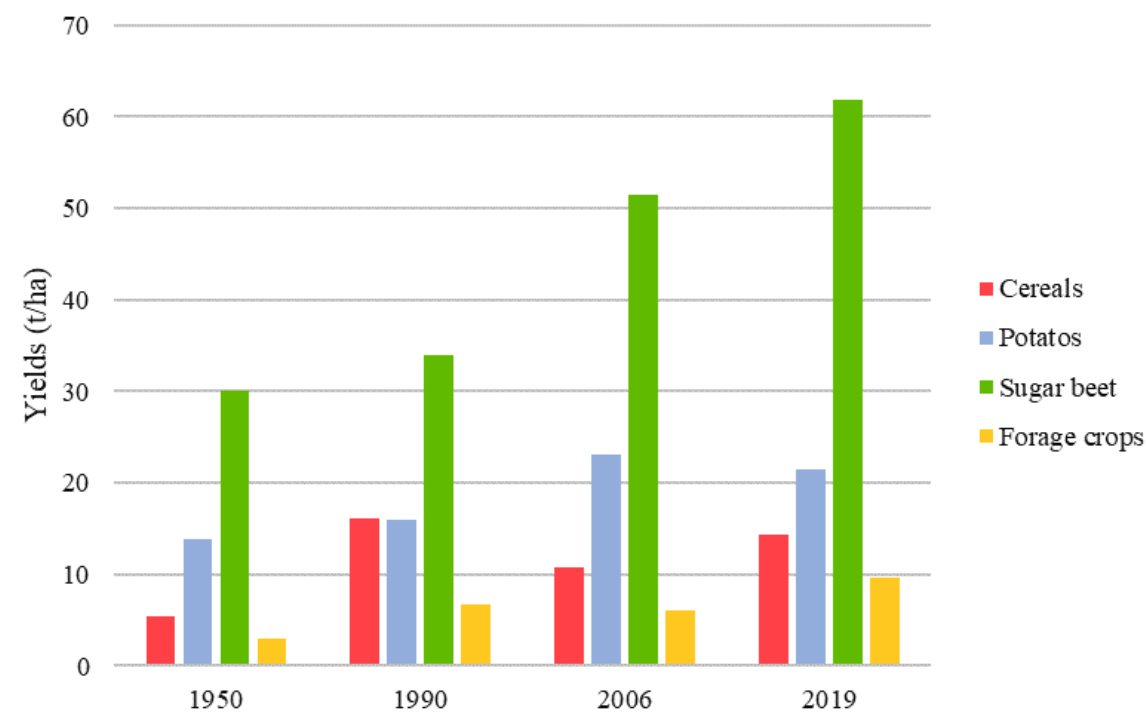

Fig. 7. Yields of selected crops in the studied time period 
and Silesia underwent a land loss of more than 1,353 thousand hectares (https://www.ceskovdatech.cz). The total loss of sowing areas can be considered as a negative phenomenon. Even though it can be compensated for by increasing yields, the agricultural land is lost at the expense of claims for building land. According to some estimates, in this way the Czech Republic annually loses up to 5,000 hectares of arable land (Ministry of Agriculture CR, 2019; Janků et al. 2016). However, one of the positive trends is the increasing hectare yield of the main field crops.

\section{RECAPITULATION}

The level of agricultural production cannot be compared with that of the middle of last century. Agriculture has marked significant improvements in growing of highly productive cultivars, as well as utilization of novel agrotechnological approaches, fertilizers and pesticides. Agricultural production has thus become a modern industry exploiting scientific data from several fields such as biology, chemistry, electrical and mechanical engineering. Particularly after 1989, agriculture underwent extensive restructuration resulting from opening of the borders and changeover to market economy. Accession to the EU and incorporation to the Common Agricultural Policy led to additional establishment of regulatory tools for management of particular agricultural commodities, which was also reflected by the changes in sowing areas for various agricultural crops. Cereals remained the most extensively grown crops and currently cover roughly 1.6 mil. ha (including winter rapeseed). The acreage of the areas for growing sugar beet, one of the few surviving broadleaf crops, dropped to one third of that 20 years ago (Chochola, 2010; Chochola, 2020). Before WW2, the Czech Republic was at the top of European market with sugar. The prerequisite for preserving this traditional position of CR as a net sugar exporter is to cultivate sugar beet in a stabilized area of at least 75,000 ha (Kozák, 2000). Moreover, according to Strategy of the Ministry of Agriculture CR 2020-2030, the self-sufficiency in growing sugar beet, despite the fact that its yields continuously reach more than $100 \%$ (with collapses between 2006-2008), dropped by $20 \%$ between the years 2004-2014. So far, the selfsufficiency in growing cereals and rapeseed has been adequate (regularly 120-140\%). However, food self-sufficiency should be perceived as associated with preservation of land potential for growing agricultural crops. Beside land claims, the Czech Republic also deals with soil degradation due to erosion and contamination (Sarapatka et al., 2010). In the last 20 years, the traditional structure of crop rotations in agriculture with interconnected plant and animal production has become a thing of the past. This usually results in inadequate supply of organic fertilizers to the soil, introduction of poor crop rotation with alternating best marketed crops with highest yields and low care for preserving soil fertility for the future. Crop yields are maintained or increased by intensification of their cultivation and breeding. This form of agriculture is not sustainable in the long term, because it is associated with both reduced soil fertility and reduction of the landscape value of the agricultural space.

In the European context, there are strong legal tools for preserving the atmosphere, wildlife, but not land. Still, land is an exhaustible, irreplaceable, and in the time horizon of several generations, a non-renewable source fulfilling a number of significant productive and ecological functions (Erdogan et al., 2021). The changes in the landscape structure are associated with the changes in the retention capacities of the region, its temperature and moisture conditions. Efforts should concentrate on increasing the care of land, preservation of its fertility and quality, and attenuation of the loss of agricultural land at the expense of developed areas (Pacheco et al. 2020). The presented study, conducted in a suburban locality designated as a beet-producing area, does not fully address all the issues associated with agricultural production and continuous loss of land, but it illustrates the general trend of increasing land claims, while continuously growing yields of strategic commodities at the expense of exploiting soil productivity will someday probably hit their limits.

\section{Acknowledgements}

This study was part of projects TA 04030363 , NAZV QK1710197 and MZE RO2018 supported by the Ministry of Agriculture of the Czech Republic. 


\section{REFERENCES}

1. Erdogan H.E., Havlicek E., Dazzi C., Montanarella L., et al. 2021. Soil conservation and sustainable development goals(SDGs) achievement in Europe and central Asia: Which role for the European soil partnership? International Soil and Water Conservation Research, 9(3), 360-369.

2. Chochola J. Guide for growing sugar beet. Beet Institute in Semčice, 2010. (in Czech)

3. Chochola J. 2020. Sugar beet 2020 at half-time. Listy cukrovarnicke a reparske, 136(7-8).

4. Janků J., Jakšík O., Kozák J., Marhoul A.M. 2016. Estimation of land loss in the Czech Republic in the near future. Soil \& Water Res.

5. Kotyza P., Smutka L., Pawlak K. 2019. Changes in sugar beet production in the Czech Republic and Poland after the year 2020. Journal of Central European Agriculture, 20(3), 1023-1043.

6. Kozák S. 2000. Status and perspectives of sugar beet cultivation in CR and worldwide. Proceedings of the conference „Beet Growing 2000" AF CAU. http://www.agris.cz/detail. php?id=174169\&iSub=518 (in Czech)

7. Ministry of Agriculture CR. 2019. Green report, 2019 [cit. 2020-10-10]. Available at: http://eagri.cz/public/web/mze/zemedelstvi/publikace-a-dokumenty/ zelene-zpravy/zelena-zprava-2018.html. (in Czech)

8. Ministry of Agriculture CR, 2019. Situation and prospective report - Sugar-sugar beet, 2019. [cit.
2020-10-10]. Available at: <http://eagri.cz/public/ web/file/655290/CUKR_12_2019.pdf > (in Czech)

9. Ministry of Agriculture CR. 2018. Situation and prospective report - Land, 2018 [cit. 2020-10-10]. Available at: <http://eagri.cz/public/web/mze/ zemedelstvi/publikace-a-dokumenty/situacni-avyhledove-zpravy/puda/> (in Czech).

10. Pacheco F.A.L. 2020. Sustainable Use of Soils and Water: The Role of Environmental Land Use Conflicts. Sustainability, 12(3), 1163. https://doi. org/10.3390/su12031163

11. Pulkrábek J., Pacek L., Čítek J., Stupka R., Pračke K., Tlustoš P. 2019. Regional food and feed selfsufficiency related to the climate change and animal density - a case study from the Czech Republic. Plant Soil Environ, 65, 244-252.

12. Sarapatka B., Bednar M., Novak P. 2010. Analysis of Soil Degradation in the Czech Republic: GIS Approach Soil and Water Research, 5(3), 108-112.

13. Strategy of the Ministry of Agriculture CR 20202030 (in Czech).

14. Žalud Z., Hlavinka P., Růžek P., Klem K., Zahradníček P., Štěpánek P., Možný M., Trnka M. 2020. Climate change and its impact on field production focused on sugar beet in the Czech Republic. Listy cukrovarnicke a reparske, 136(7-8).

15. https://www.ceskovdatech.cz/clanek/52-v-ceskuubyva-osevnich-ploch-jde-ale-o-dusledekprirozeneho-vyvoje/\#article-content (in Czech). 